\title{
Investigations on Deposit Formation in the Holes of Diesel Injector Nozzles
}

\author{
Andreas Birgel, Nicos Ladommatos, Pavlos Aleiferis \\ University College London \\ Nebojsa Milovanovic, Paul Lacey \\ Delphi Diesel Systems, UK \\ Paul Richards \\ Innospec Limited
}

Copyright (? 2011 Society of Automotive Engineers of Japan, Inc.

\begin{abstract}
Current developments in fuels and emissions regulations are resulting in an increasingly severe operating environment for diesel fuel injection systems. The formation of deposits within the holes or on the outside of the injector nozzle can affect the overall system performance. The rate of deposit formation is affected by a number of parameters, including operating conditions and fuel composition. For the work reported here an accelerated test procedure was developed to evaluate the relative importance of some of these parameters in a high pressure common rail fuel injection system. The resulting methodology produced measurable deposits in a custom made injector nozzle on a single cylinder engine. The results indicate that fuels containing $30 \% \mathrm{v} / \mathrm{v}$ and $100 \%$ Fatty Acid Methyl Ester (FAME), that does not meet EN 14214 produced more deposit than an EN590 petroleum diesel fuel. Overall, the addition of zinc to the fuel had the biggest effect on deposit formation and resulted in a $12.2 \%$ decrease in Indicated Mean Effective Pressure (IMEP). The effects of zinc were unexpectedly reduced when it was added to fuel containing $30 \% \mathrm{v} / \mathrm{v}$ biodiesel. Reducing the common-rail pressure with $30 \% \mathrm{v} / \mathrm{v}$ biodiesel (no added zinc) increased the loss in IMEP. Raising the air and fuel temperatures by $40^{\circ} \mathrm{C}$ and $30^{\circ} \mathrm{C}$ respectively showed no bigger loss in IMEP. The results indicate that deposit formation may continue after engine shut down.
\end{abstract}

\section{INTRODUCTION}

Significant pressure exists to improve the fuel economy and $\mathrm{CO}_{2}$ emissions of passenger cars, often reinforced by legislative demands directed towards strict emissions and fuel economy limits. The common rail fuel injection system plays a central role in achieving these requirements through more accurate and more frequent injections per cycle at higher fuel rail pressures. As a result, the overall system design including the nozzle is evolving rapidly to optimize spray quality and control. The latest injector designs balance these parameters to optimise performance while maintaining durability even under the most demanding operating conditions.

The formation and the removal of deposits in any location in an engine was described by Lepperhoff and Houben [1]. A mechanism for the formation of deposits in injector nozzles was described by Caprotti [2] and is shown in Figure 1. The resulting deposits have the potential to restrict the hydraulic flow in the nozzle holes, thereby reducing maximum flow rate and engine power. Such deposits can also affect the fuel spray quality, resulting in increased fuel consumption and emissions [3, 4].

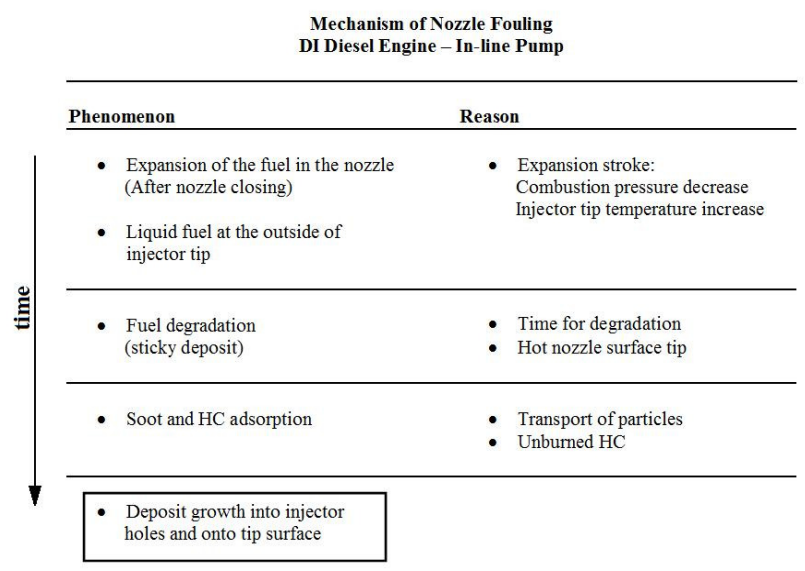

Figure 1 Mechanism of Deposit Formation [2] 
Previous publications have identified three main influences on injector deposits: nozzle geometry, fuel composition and temperature [5]. The geometry of the nozzle design as an influence was identified by Argueyrolles et al. [6]. Streamlining reduces the turbulence and cavitation in the fuel, which may have the effect of reducing the ability of the fuel to remove deposits from the nozzle. Modern nozzles are designed to minimise energy losses due to cavitation, raising the possibility that deposits may form more easily with this design.

At the same time, Fatty Acid Methyl Ester (FAME) is rapidly becoming more widely used as a fuel component in compression ignition engines. Some publications show that FAME can cause increased nozzle hole deposits [7]. The influence of $5 \% \mathrm{v} / \mathrm{v}$ biodiesel was investigated by [8] and the influence of $10 \% \mathrm{v} / \mathrm{v}$ biodiesel was instigated by $[9,10,11]$. Overall, the effect of biodiesel remains unclear.

Small concentrations (1-3ppm) of zinc have long been recognised as a major influence on injector coking [12, 13 , 14]. A number of other publications have discussed the role of zinc, either as a catalyst or as a deposit component $[9,14]$. Pick up of zinc is possibly aggravated by use of aged or acidic biodiesel or through use of acidic lubricity additives [12], although such additives are becoming increasingly rare. An industry standard engine test exists for evaluation of nozzle coking tendency using $3 \mathrm{ppm}$ zinc to promote deposit formation [15]. The relationship of this test procedure to real world driving is discussed in [10].

A critical temperature of $300^{\circ} \mathrm{C}$ is mentioned as raising the amount of injector coking by thermal condensation and cracking reactions, see [16].

\section{MAIN SECTION}

\section{EXPERIMENTAL APPROACH AND TEST METHODOLOGY}

\section{SINGLE CYLINDER ENGINE TEST}

A test methodology was required that produced measurable and repeatable deposits within a reasonable test duration. The mechanism outlined in Figure 1 shows that deposits are affected by the combustion process, including the compression and expansion of combustion gasses through the nozzle holes. These gasses contain combustion products and soot, as well as volatilized crankcase lubricant and additives, which contain zinc and phosphorous. As a result, a fired engine test is unavoidable.

A single-cylinder engine, based on the Ricardo Hydra experimental engine design was built. The engine head and piston were taken from a commercially available 4-cylinder 2.0 litre high speed turbocharged automotive diesel engine equipped with a common rail injection system. The engine cylinder bore and stroke were both $86 \mathrm{~mm}$ and the piston was of the bowl-in-piston design. An adaptor plate was used to convert the 4-cylinder head so that only cylinder no. 1 was operational.

An external supercharger air system was designed and installed. A screw-compressor driven by a variable speed electrical motor was used to pressurise the air which was cooled using a heat exchanger. As a result, the temperature and pressure of the air in the engine manifold could be independently controlled. The exhaust back pressure was set with a fixed exhaust gas throttle before all engine tests and no Exhaust Gas Recirculation (EGR) was used for any of the tests.

The instantaneous in-cylinder pressure was measured using a piezo-electric quartz pressure transducer, which was installed via a glow plug adaptor. The air-manifold pressure, in-cylinder pressure and exhaust pressure were recorded every 0.2 Crank Angle Degrees (CAD), timed by an optical shaft encoder driven from the engine crankshaft. Engine speed, torque, air inlet- and exhaust-temperature were recorded. Fuel consumption was measured with an AVL gravimetric fuel balance. Engine Brake Mean Effective Pressure (BMEP) was obtained from measurements of the torque reaction on the engine brake, monitored by means of a load cell. Indicated Mean Effective Pressure (IMEP) was instantaneously calculated from the in-cylinder pressure. Specially written data acquisition and analysis software allowed heat release analysis to be performed continuously while the testing was in progress.

The control system for the fuel injection system allowed free control of all injection parameters. The fuel injection system was based on a modern common-rail design with a servo-hydraulic injector containing a non production nozzle. The nozzle had 7 holes and was of a $\mu$-sac design with a high discharge coefficient $(\mathrm{Cd})$ value likely to produce minimal or no cavitation. This tended to accelerate the rate of deposit formation relative to production equipment, while maintaining the same overall trends. A new injector having a new nozzle set was fitted to the engine prior to each test. All injectors were run-in to give their optimum performance at the start of each test.

Prior to starting the engine, electrical heaters were used to warm the crankcase lubricant and coolant for approximately 20 minutes. The engine was then started and the engine speed was increased accompanied by increasing load. A load sweep was performed at a constant air temperature of $55^{\circ} \mathrm{C}$. For this load sweep, the injection duration was increased stepwise until the operating point was reached. A full set of measurements was taken at each point. The last point of the load sweep was the high load point of the test cycle. This point was used as reference point / nominal point for any drop in IMEP. This point is represented in the subsequent plots as a solid marker. After the load sweep, the main test cycle started and the air temperature was further increased to $70^{\circ} \mathrm{C}$ $\left(30^{\circ} \mathrm{C}\right.$ for Test No. 3). At the end of the test cycle the same load sweep was performed but with a stepwise decrease in the injection duration. This was done, to allow any drop in IMEP to be measured over multiple 
load points. In the subsequent plots this is again represented by the solid marker, whilst the continuous lines represent the measurements made throughout each test day.

The main engine load cycle consisted of cycling the load for 10 minutes at high load followed by 10 minutes at very low load - almost engine motoring condition. These high and low load conditions were defined by a fixed injection pulse duration. At the low load motoring condition, only a small quantity of fuel was injected, at common rail pressure 400bar and $300 \mu \mathrm{sec}$ injection duration. This was done to maintain diesel fuel in the nozzle holes, to encourage the build up of further deposits. During the test cycle the high load and low load injection durations were kept constant, so that any deposits in the holes of the injector could be observed as a drop in IMEP and BMEP and thereby a reduction in engine power output. The test cycle was repeated on two consecutive days with a shut down period over night.

Further details of the test matrix, including the engine operating conditions, are shown in Table 1. During the tests the fuel temperature was normally set to $60^{\circ} \mathrm{C}$ and the air temperature was set to $70^{\circ} \mathrm{C}$. Test No. 2 was performed with a constant load instead of cycling load. Test No. 3 was run at $35^{\circ} \mathrm{C}$ fuel temperature and $30^{\circ} \mathrm{C}$ air temperature to ascertain the effects of temperature, while Test No 4 was performed to define the effects of injection pressure. The engine speed was always constant at 2800 RPM and the boost pressure was constant at 1.98 bar.

Table 1 Engine test matrix and engine operating details

\begin{tabular}{|l|l|l|l|l|l|}
\hline $\begin{array}{l}\text { Test } \\
\text { No. }\end{array}$ & $\begin{array}{l}\text { Fuel } \\
\text { Comp. }\end{array}$ & $\begin{array}{l}\text { Load } \\
\text { Cycle }\end{array}$ & $\begin{array}{l}\text { Fuel } \\
\text { Temp. } \\
{\left[{ }^{\circ} \mathbf{C}\right]}\end{array}$ & $\begin{array}{l}\text { Air } \\
\text { Temp. } \\
{\left[{ }^{\circ} \mathbf{C}\right]}\end{array}$ & $\begin{array}{l}\text { Fuel } \\
\text { Press. } \\
{[\text { bar }]}\end{array}$ \\
\hline $\mathbf{1}$ & $\begin{array}{l}30 \% \text { VAME } \\
\text { (B30) }\end{array}$ & Cyclical & 60 & 70 & 700 \\
\hline $\mathbf{2}$ & B30 & Constant & 60 & 70 & 700 \\
\hline $\mathbf{3}$ & B30 & Cyclical & $\mathbf{3 5}$ & $\mathbf{3 0}$ & 700 \\
\hline $\mathbf{5}$ & $\begin{array}{l}\text { B30 } \\
\text { B0 }\end{array}$ & Cyclical & 60 & 70 & $\mathbf{1 1 0 0}$ \\
\hline $\mathbf{6}$ & $\begin{array}{l}\mathbf{1 0 0} \% \\
\text { FAME } \\
\text { (B100) }\end{array}$ & Cyclical & 60 & 70 & 700 \\
\hline $\mathbf{7}$ & $\begin{array}{l}\text { B0 +3 } \\
\text { ppm Zn }\end{array}$ & Cyclical & 60 & 70 & 700 \\
\hline $\mathbf{8}$ & $\begin{array}{l}\text { B30+3 } \\
\text { ppm Zn }\end{array}$ & Cyclical & 60 & 70 & 700 \\
\hline & & 60 & 70 & 700 \\
\hline
\end{tabular}

\section{TEST FUELS}

As previously discussed, some of the fuel variables likely to affect deposit formation are zinc and biodiesel concentration. Reference diesel (B0 / RF06) was used as the base fuel, this fuel was chosen since it did not contain any biodiesel or performance additives. The principal characteristics of this fuel are detailed in Table A-1 and A-3 in the appendix and confirm that it contains low levels of zinc and other elements.

The biodiesel used was based on transesterified used vegetable cooking oil. The batch used for this work did not meet the EN14214 standard for pure FAME, as shown in Table A-2. Elemental analysis is provided in Table A-3. The sodium content is relatively high in the bio-fuel, which is probably due to the use of sodium hydroxide as a catalyst during the transesterification process. Engine tests were performed with both the pure biodiesel (B100) and a blend (B30) of $30 \% \mathrm{v} / \mathrm{v}$ biodiesel with $70 \% \mathrm{v} / \mathrm{v}$ of the RF06 reference diesel fuel.

A number of tests were performed with 3 ppm of zinc added to the fuel. This was achieved with the addition of zinc neodecanoate. The zinc compound was added to the RF06 reference fuel for test No. 7 and to the B30 blend for test No. 8 .

\section{RESULTS}

\section{INFLUENCE OF TEST CYCLE}

Several preliminary tests were performed to optimize and validate the engine test conditions. This test sequence was performed using B30 fuel, which caused measurable deposits.

Tests No. 1 and 2 were performed to define the effects of cyclical versus constant load conditions. In Test 1 , the engine was operated at the test conditions described in Table 1, which gave a nominal starting IMEP of ca. 13.4bar. Test No. 2 was conducted with steady state load instead of the cycling load. The remaining conditions of the two tests were identical.

The results are plotted in Figure 2 as a function of test duration. A decrease in IMEP is observed with both test conditions. The cyclically varying test produced a larger decrease in IMEP (4.1\%) than the constant load test $(2.88 \%)$. It is likely that the low load portion of the cyclical load test maintains a small amount of fuel in the nozzle holes, to encourage the build up of further deposits. All subsequent tests were performed with varying load. 


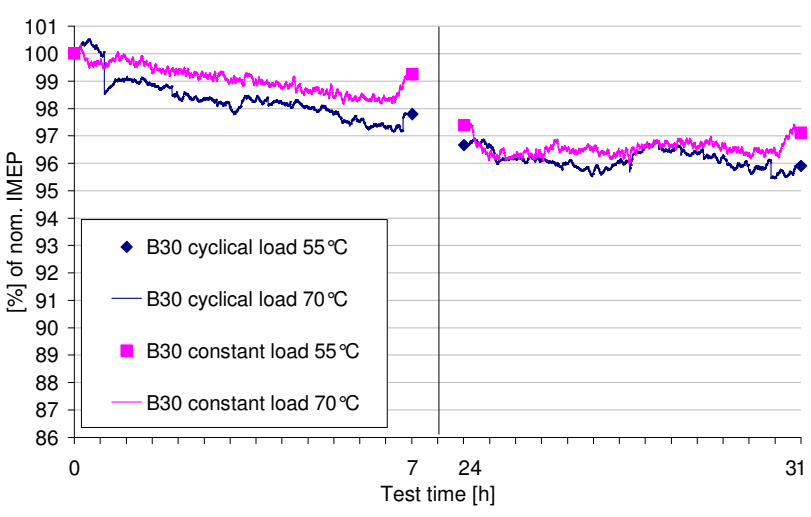

Figure 2 Comparison of Engine Tests Performed at Constant and Cyclically Varying Load, (Tests No. 1 and 2 in Table 1) (The continues lines represent the measurements made throughout each test day, while the discreet points [square, diamond] represent measurements made at the start and the end of each test day)

\section{INFLUENCE OF FUEL AND AIR TEMPERATURE}

To investigate the effect of temperature Test No. 3 was run with a fuel temperature of $35^{\circ} \mathrm{C}$ and an air temperature of $30^{\circ} \mathrm{C}$. The results are plotted in Figure 3. The baseline test at $60^{\circ} \mathrm{C}$ fuel temperature and $70^{\circ} \mathrm{C}$ air temperature with the same fuel (Test No. 1) is also plotted. The results indicate a very similar change in IMEP occurred at both temperatures. All subsequent tests were performed at $60^{\circ} \mathrm{C}$ fuel temperature and $70^{\circ} \mathrm{C}$ air inlet temperature. No attempt was made to run tests with a fuel temperature higher than $60^{\circ} \mathrm{C}$, as this resulted in unacceptably high temperatures at other parts of the fuel system.

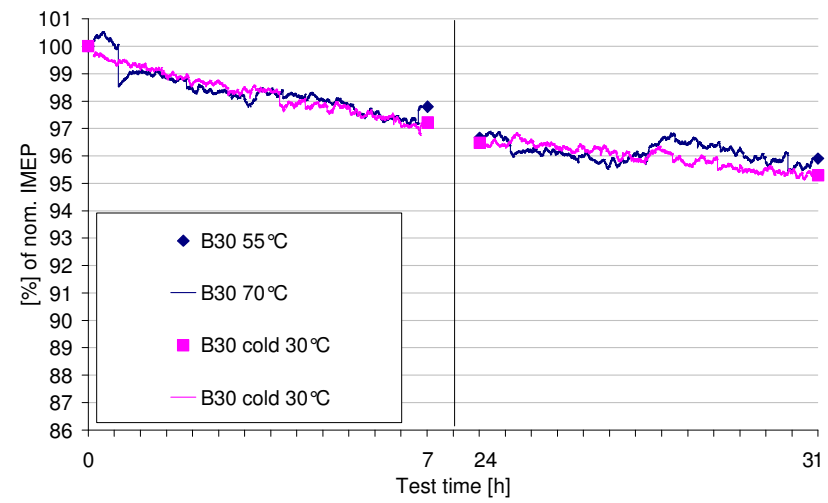

Figure 3 Influence of Air and Fuel Temperature (Tests No. 2 and 3 in Table 1)

\section{INFLUENCE OF COMMON RAIL PRESSURE}

To investigate the influence of common-rail pressure, Test No. 4 was performed with a common-rail pressure of 1100 bar in comparison to the 700 bar used in the remaining tests. To compensate for the higher injection pressure the injection duration was reduced from $2000 \mu \mathrm{sec}$ to $1550 \mu \mathrm{sec}$, which resulted in a starting load of ca. 14.9 bar IMEP at the beginning of the test. The percentage change in measured IMEP is plotted in Figure 4 as a function of test duration together with Test No. 1 as a baseline for comparison. A drop of $1.9 \%$ in IMEP is observed at 1100 bar compared to $4 \%$ at 700 bar. This indicates that a lower common-rail pressure, which results in less cavitation and shear stresses in the nozzle holes, results in more deposits.

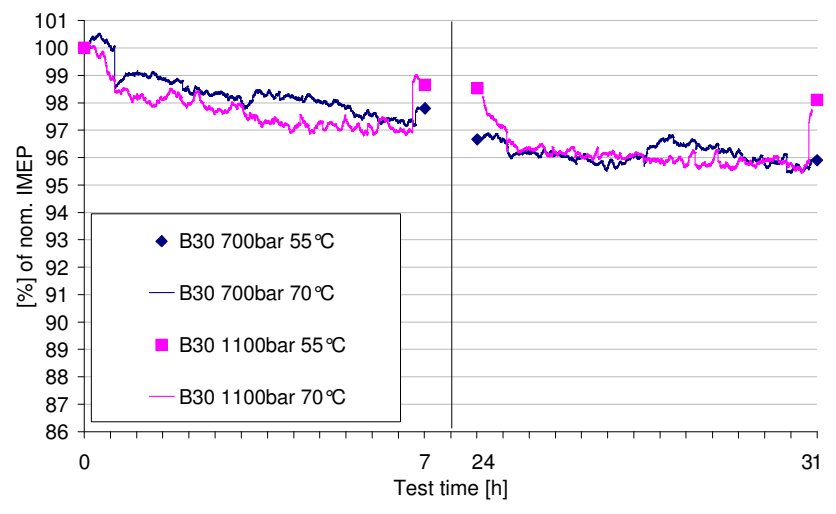

Figure 4 Influence of Common-Rail Pressure (Tests No. 1 and 4 in Table 1)

\section{INFLUENCE OF FUEL COMPOSITION}

\section{FATTY ACID METHYL ESTER (FAME)}

The results of Engine Tests No. 2, 5, 6 are plotted in Figure 5 and show the effect of B0 (RF06), B30 and B100 on deposits, measured by a drop in IMEP. The results indicate that B0 (RF06) showed ca. 1.9\% loss in IMEP, while B30 and B100 produced ca. $4.1 \%$ and ca. $7.5 \%$ respectively over 14 hours of testing. This indicates that both the B30 and B100 blends of off-specification biodiesel accelerated the deposit formation. For B0 and B30 fuels the drop in IMEP on the first day was higher than that observed on the second day, suggesting a diminishing accumulation of deposits with test time. The rate of deposit formation with the poor quality B100 fuel showed no sign of decrease during the test duration.

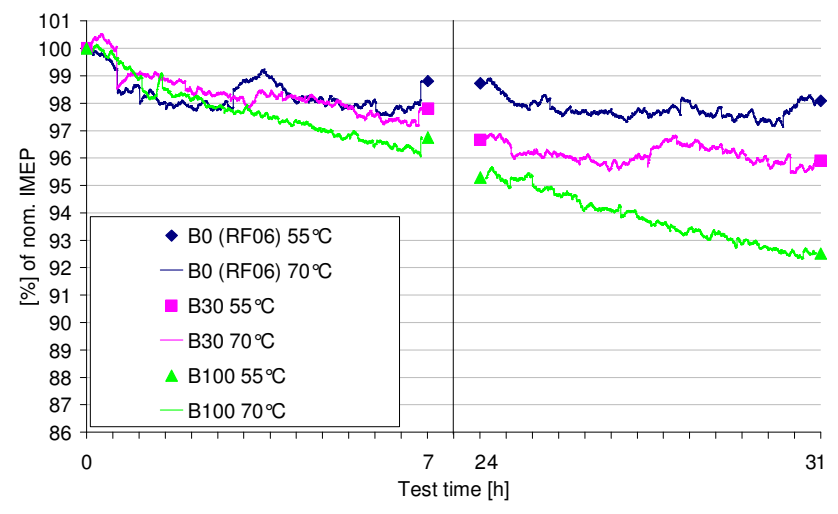

Figure 5 Influence of FAME on Reduction in IMEP (Tests No. 2, 5 and 6 in Table 1). 


\section{ZINC}

Published sources show that zinc concentrations of $3 \mathrm{ppm}$ or less in the fuel may accelerate the rate of deposit formation in the nozzle holes. Engine Test No. 7 was performed with B0 (RF06) fuel treated with $3 \mathrm{ppm}$ of zinc, which is broadly comparable to the concentrations used by other researchers and in the industry standard test [15]. The results plotted in Figure 6 indicate that this produced a 12.2\% drop in IMEP after 14 hours, which is considerably higher than that produced by the B0 (RF06) fuel. In the literature a loss in torque between ca. $11.8 \%$ and $17.25 \%$ for 3ppm zinc are shown in reference [13]. This indicates that the results obtained using the present methodology are comparable to those from the DW10 test method, which also uses zinc addition to the fuel. Again a drop in IMEP occurred overnight. It should be noted, that the test with the B0 (RF06) with 3ppm zinc showed a visible drop in IMEP after each low load point. This underlines the importance of low load points in the test cycle.

Engine Test No. 8 was performed with $3 \mathrm{ppm}$ of zinc added to the B30, with the results also plotted in Figure 6. The combination with B30 appears to reduce the effect of the zinc, as the IMEP dropped by $6.8 \%$ compared to $12.2 \%$ for the addition of Zinc to the B0 (RF06).

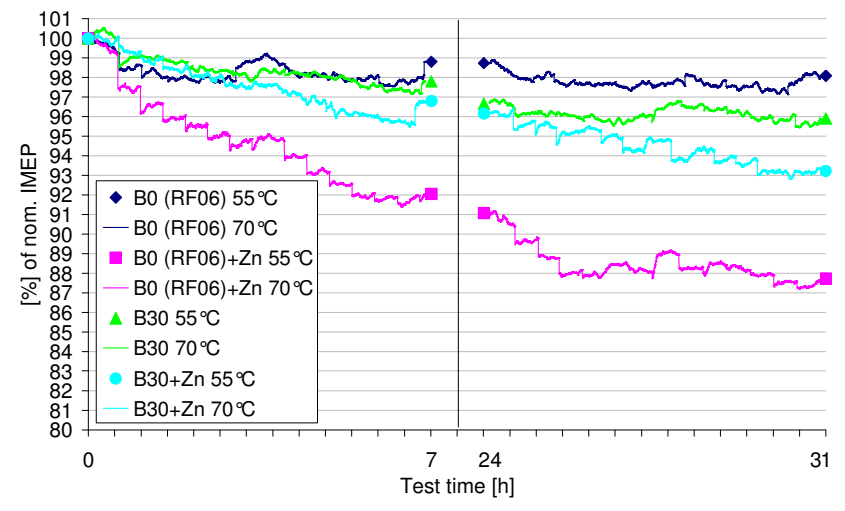

Figure 6 Influence of Zinc Addition on Deposits (Test No. 2, 5, 7 and 8 in Table 1)

\section{VISUAL COMPARISON OF NOZZLE EXTERIORS}

Some investigators have attempted to visually rate the outside of the injector tip as a measure of deposits [17, $18,19,20]$. Table 2 contains photographs of the exteriors of the nozzles after the tests from the present study, arranged in order of increasing change in IMEP. A new and unused nozzle is also included for comparison.

Little relationship is apparent between the visible exterior deposit and the measured change in IMEP. In fact the exterior of the nozzle operated with RF06 base fuel appears as discoloured as the tests performed with $3 \mathrm{ppm}$ zinc contamination that produced almost an order of magnitude greater loss in IMEP. In general, the heaviest visible deposit is present in those tests performed with biodiesel. In particular, the nozzle operated with B100 has a large amount of external deposit.

\section{Table 2: Photographs of Exterior of Nozzle Tips}

\begin{tabular}{|c|c|c|c|}
\hline $\begin{array}{l}\text { Test } \\
\text { No. }\end{array}$ & Fuel & $\begin{array}{l}\text { IMEP } \\
\text { Loss } \%\end{array}$ & Photograph \\
\hline $\mathrm{N} / \mathrm{A}$ & $\begin{array}{l}\text { New } \\
\text { Nozzle }\end{array}$ & 0 & \\
\hline 5 & $\begin{array}{l}\text { RF06 } \\
\text { Base } \\
\text { Fuel } \\
\text { (B0) }\end{array}$ & 1.9 & \\
\hline 2 & $\begin{array}{l}\text { RF06 + } \\
30 \% \mathrm{v} / \mathrm{v} \\
\text { FAME } \\
\text { (B30) }\end{array}$ & 4.1 & \\
\hline 8 & $\begin{array}{l}\text { RF06 + } \\
30 \% \text { v/v } \\
\text { FAME + } \\
\text { 3ppm } \\
\text { Zinc }\end{array}$ & 6.7 & \\
\hline 6 & $\begin{array}{l}100 \% \\
\text { FAME } \\
\text { (B100) }\end{array}$ & 7.4 & \\
\hline 7 & $\begin{array}{l}\text { RF06 + } \\
\text { 3ppm } \\
\text { Zinc }\end{array}$ & 12.2 & \\
\hline
\end{tabular}

\section{DISCUSSION}

A test methodology was developed which produces deposits in the nozzle holes of diesel fuel injectors. The test uses a single cylinder supercharged engine of 0.5 litre swept volume based on a commercially available high speed DI automotive engine. The common rail injection system was fitted with a non-production nozzle that produces minimal cavitation to accelerate deposit formation.

The results are summarised in Figure 7 and indicate that the rate of deposit formation is strongly sensitive 
to fuel composition, specifically the presence of off-specification biodiesel and zinc. Surprisingly, the effects of zinc are halved by the addition of $30 \% \mathrm{v} / \mathrm{v}$ biodiesel. One might speculate that this unexpected effect may be due to the fact that the highly polar biodiesel is a good solvent. However, at this time there is no explanation for this phenomenon.

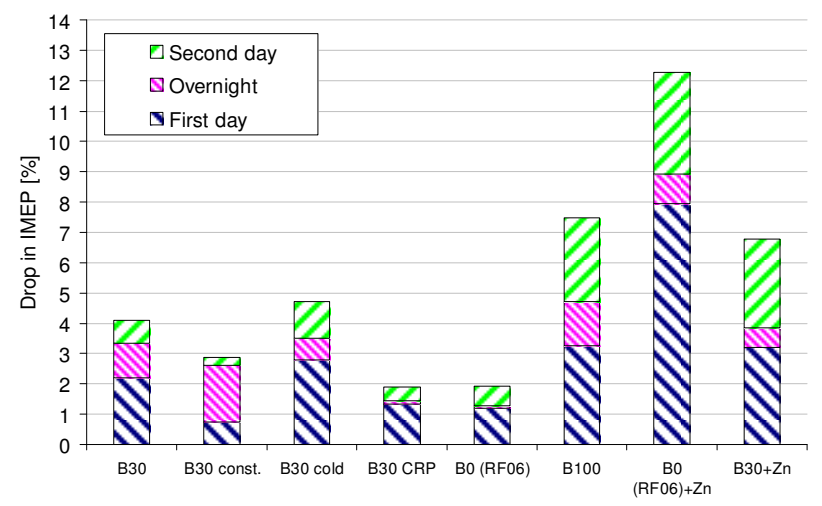

Figure 7: IMEP Losses Observed in the Various Tests

The engine test procedure consisted of two 7 hour test sequences on subsequent days with an overnight shut down in between. The measured IMEP was normally lower at the beginning of the second days testing than at conclusion of the first days. This suggested that the deposit formation continued during shut down over night. As would be expected, this effect was reduced for tests that showed little overall loss in IMEP e.g. at the tests with B0 (RF06) or a higher common-rail pressure. The rate of deposit formation following engine shut down was lower than that during engine operation, but typically ranged from 0.5 to $2 \%$ loss in IMEP over the 17 hours of inactivity. The mechanism for deposit formation following engine shut down has not been conclusively defined. However, it is likely to be related to the residual fuel trapped within the nozzle sac and holes after the engine shut down.

In general, the rate of deposit formation (as reflected by IMEP decrease) was greatest in the first 7 hours of testing and decreased in the second 7 hours of testing on the following day. This indicates that a stable condition may eventually be achieved in which no further increase in deposit thickness will occur. This is due to a balance being created between the rate of accumulation and removal of deposit as it is described in [1]. As would be expected, this steady state condition appears to be achieved more rapidly for conditions that result in slow deposit accumulation, such as with B0 (RF06) fuel or at higher common-rail pressures.

The effects of deposit formation were reflected by a decreasing IMEP measured during the engine tests. In every instance, a corresponding drop in fuel consumption and exhaust temperature were observed. An equivalent drop in the heat-release rate was also measured, which is shown in Figure 8. This diagram represents the average over 500 thermodynamic cycles, taken at an engine speed of 2800rpm with a load of 13.66 bar IMEP at the start of the first day.

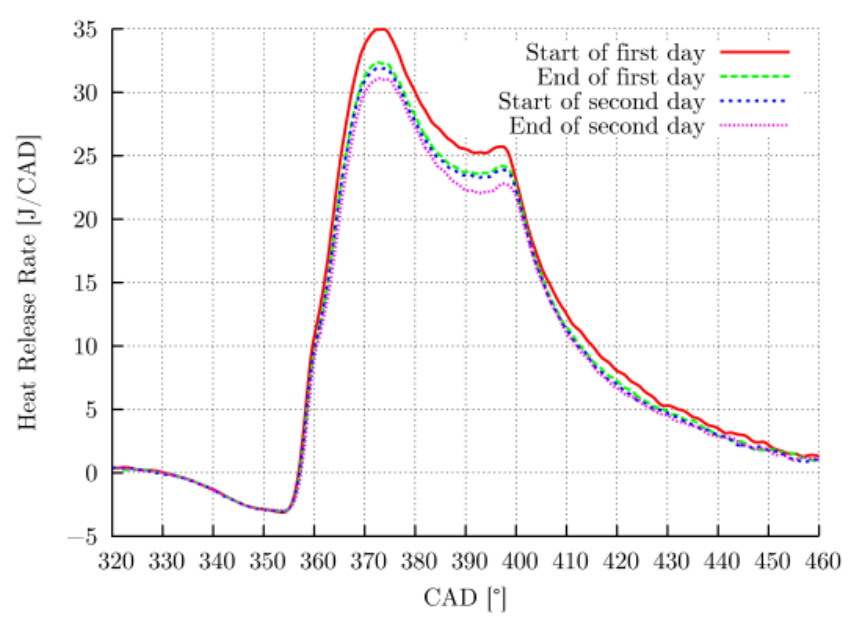

Figure 8 Drop in heat release rate (HRR) (Test No. 7, B0 (RF06) +3ppm Zn)

\section{CONCLUSION}

The following conclusions may be drawn as a result of this study:

1. An accelerated test methodology has been developed that produces deposits in the nozzle holes of diesel fuel injectors. The quantity of deposits is sufficient to adversely affect engine performance as measured by IMEP.

2. Relatively little deposit occurred with a reference diesel fuel which did not contain either FAME or zinc, even though that fuel does not contain any deposit control additives.

3. Deposits were increased through the use of B30 and further increased through the use of B100, causing a $4.1 \%$ and $7.4 \%$ decrease in IMEP respectively. In both instances a poor quality biodiesel was used that did not meet EN14214.

4. The presence of 3ppm zinc had the largest effect on deposit formation, resulting in a $12.2 \%$ decrease in IMEP during a test with B0 (RF06) fuel.

5. The detrimental effects of zinc were reduced if it was added to B30.

6. In each instance, the decrease in IMEP was matched by a corresponding decrease in fuel consumption and exhaust temperature.

7. In general, the rate of deposit formation (as reflected by IMEP decrease) decreased with test duration particularly for B0 (RF06) or B30, which indicates that a steady state condition may eventually achieved between formation and removal.

8. Deposit formation continued following engine shut down. As a result, the IMEP at the beginning of the second days testing was normally lower than that recorded at the end of the first days testing

9. Visual inspections suggest that there is no correlation between the quantity of deposit on the outside of the injector nozzle tip and the loss of power output from the engine. In particular the nozzle used with fuel that contained zinc showed a very high IMEP loss with little external deposits, while the poor quality biodiesel caused heavy external deposits. 


\section{ACKNOWLEDGMENTS}

The authors would like to acknowledge financial and technical support provided by Delphi Diesel Systems and Innospec Ltd.

\section{REFERENCES}

1. Lepperhoff G., Houben M., "Mechanisms of Deposit Formation in Internal Combustion Engines and Heat Exchangers", SAE Technical Paper 931032, 1993.

2. Caprotti R., Fowler W. J., Lepperhoff G., Houben M., "Diesel Additive Technology Effects on Injector Hole Erosion/corrosion, Injector Fouling and Particulate Traps", SAE Technical Paper 932739, 1993.

3. Richards P., Walker R.D., Williams D., "Fouling of Two Stage Injectors - An Investigation into Some Causes and Effects", SAE Technical Paper 971619, 1997.

4. Winterbone D. E., Clough E., Rao K. K., Richards P. Williams D., "The Effect of DI Nozzle Fouling on Fuel Spray Characteristics", SAE Technical Paper 922232, 1992.

5. Birgel A., Ladommatos N., Aleiferis P., Zülch S., Milovanovic N., Lafon V., Orlovic A., Lacey P., Richards P., "Deposit Formation in the Holes of Diesel Injector Nozzles: A Critical Review", SAE Technical Paper 2008-01-2383, 2008.

6. Argueyrolles B., Dehoux S., Gastaldi P., Grosjean L., Levy F., Michel A., Passerel D., "Influence of injector nozzle design and cavitation on coking phenomenon", SAE 2007-01-1896, JSAE 20077184, 2007.

7. Sem T. R., "Investigation of Injector Tip Deposits on Transport Refrigeration Units Running on Biodiesel Fuel", SAE Technical Paper 2004-01-0091

8. Loest O., Ullmann J., Winter J. „Investigation on the Addition of FAME to Diesel Fuels", DGMK Deutsche Wissenschaftliche Gesellschaft für Erdöl, Erdgas, und Kohle e.V., Research Report 639e, Hamburg, Germany, 2007, 2007.

9. Barbour R., Arters D., Dietz J., Macduff M., Panesar A., Quigley R., "Diesel Detergent Additive Responses in Modern, High-Speed, Direct-Injection, Light-Duty Engines", SAE Technical Paper 2007-01-2001, 2007.

10. Hawthorne M., Roos J. W., Openshaw M. J., "Use of Fuel Additives to Maintain Modern Diesel Engine Performance with Severe Test Conditions", SAE Technical Paper 2008-01-1806, 2008.

11. Uitz R., Brewer M., Williams R., "Impact of FAME Quality on Injector Nozzle Fouling in a Common Rail Diesel Engine", SAE Technical Paper 2009-01-2640, 2009.

12. Leedham A., Caprotti R, Graupner O., Klaua T., "Impact of Fuel Additives on Diesel Injector Deposits", SAE Technical Paper 2004-01-2935, 2004.

13. Caprotti R., Breakspear A., Graupner O., Klaua T., "Detergency Requirements of Future Diesel
Injection System", SAE Technical Paper 2005-01-3901, 2005.

14. Caprotti R., Breakspear A., Graupner O., Klaua T., Kohnen O., "Diesel Injector Deposits Potential on Future Fueling Systems", SAE Technical Paper 2006-01-3359, 2006.

15. CEC F-98-08 (S), Direct Injection, Common Rail Diesel Engine Nozzle Coking Test. 4, 27 January 2010

16. Watkinson A. P., Wilson D. I., "Chemical Reaction Fouling: A Review", Experimental Thermal and Fluid Science, 14:361-374, Elsevier Science Inc., New York, 1997

17. Gallant T. R., Carman M. C., Gray J. T., Strete N. M., "Cummins L10 Injector Depositing Test to Evaluate Diesel Fuel Quality", SAE Technical Paper 912331

18. Blythe G. H., Flask C. A., "Development of an Image Analysis System to Rate Injectors from the Cummins L10 Injector Depositing Test", SAE Technical Paper 972902, 1997.

19. Mendoza M. C., Zhang Q., Hansen A. C., Reid J. F., "Injector Nozzle Coking With Oxygenated Diesel", SAE Technical Paper 2001-01-2016, 2001.

20. Korus R. A., Jo J., Peterson C. L, "A Rapid Engine Test to Measure Injector Fouling in Diesel Engines Using Vegetable Oil Fuels", Journal of the American Oil Chemists' Society, Vol.62, No.11, p1563-1564, 1985.

\section{CONTACT}

Nicos Ladommatos, Department of Mechanical Engineering, University College London, Torrington Place, London WC1E 7JE, UK, n_ladommatos@meng.ucl.ac.uk

\section{DEFINITIONS, ACRONYMS, ABBREVIATIONS}

B0 / RF06: Reference diesel which contains no bio-fuels or additives

B100: Fuel comprising 100\% bio-fuel

B30: Fuel blend of bio-fuel/reference diesel fuel in which bio-fuel is $30 \%$ by volume

BMEP: Brake Mean Effective Pressure

CAD: Crank Angle Degrees

EGR: Exhaust Gas Recirculation

FAME: Fatty Acid Methyl Ester

IMEP: Indicated Mean Effective Pressure 


\section{APPENDIX}

Table A-1 Analysis of Test Fuel, Reference Fuel (B0; RF06), EN 590

\begin{tabular}{|c|c|c|c|c|}
\hline Property (Units) & Method & Min & Max & Results \\
\hline Cetane Number & D613 & 52 & 54 & 53.2 \\
\hline Density @ $15^{\circ} \mathrm{C}, \mathrm{g} / \mathrm{ml}$ & D4052 & 0.833 & 0.837 & 0.8339 \\
\hline Distillation, ${ }^{\circ} \mathrm{C}$ & D86 & & & \\
\hline IBP & & TBR & & 192.5 \\
\hline $10 \%$ Vol Point & & TBR & & 221 \\
\hline $50 \%$ Vol Point & & 245 & & 272.5 \\
\hline $90 \%$ Vol Point & & TBR & & 327 \\
\hline $95 \%$ Vol Point & & 345 & 350 & 348.5 \\
\hline FBP & & & 370 & 357.5 \\
\hline Pensky Closed Flash, ${ }^{\circ} \mathrm{C}$ & D93 & 55 & & 83 \\
\hline $\begin{array}{l}\text { Cold Filter Plugging Point, } \\
{ }^{\circ} \mathrm{C}\end{array}$ & EN116 & & -5 & -23 \\
\hline Viscosity @ $40^{\circ} \mathrm{C}, \mathrm{mm}^{2} / \mathrm{sec}$ & D445 & 2.5 & 3.3 & 2.77 \\
\hline Polycyclic Aromatic, \%mass & IP391 & 3 & 6 & 4.8 \\
\hline Total Aromatics, \%mass & IP391 & TBR & & 28.7 \\
\hline Sulphur Content, mg/Kg & IP490 & & 10 & $<1$ \\
\hline $\begin{array}{l}\text { Copper Corrosion, 3hr @ } \\
100^{\circ} \mathrm{C}\end{array}$ & D130 & & 1 & $1 \mathrm{~b}$ \\
\hline $\begin{array}{l}\text { Conradson Carbon Residue } \\
\text { on } 10 \% \text { Dist. Residue, } \%\end{array}$ & D189 & & 0.2 & $<0.01$ \\
\hline Ash Content, \% mass & D482 & & 0.01 & $<0.001$ \\
\hline Water Content, mg/Kg & IP438 & & 200 & 70 \\
\hline $\begin{array}{l}\text { Neutralization (Strong Acid) } \\
\text { Number }(\mathrm{mg} \mathrm{KOH} / \mathrm{g})\end{array}$ & D974 & & 0.02 & 0.01 \\
\hline Fatty Acid Methy Ester & $\begin{array}{l}\text { EN140 } \\
78\end{array}$ & Proh. & & NIL \\
\hline Lubricity, $\mu \mathrm{m}$ & $\begin{array}{l}\text { ISO121 } \\
56-1\end{array}$ & & 400 & 316 \\
\hline $\begin{array}{l}\text { Oxidation Stability, } \\
\mathrm{mg} / 100 \mathrm{ml}\end{array}$ & D2274 & & 2.5 & 0.1 \\
\hline Cloud Point, ${ }^{\circ} \mathrm{C}$ & D2500 & TBR & & -20 \\
\hline Water \& Sediment, \%v/v & D2709 & TBR & & NIL \\
\hline Fuel H/C Atomic Ratio & Calc. & TBR & & 1.84 \\
\hline Fuel O/C Atomic Ratio & Calc. & TBR & & $<0.0003$ \\
\hline $\mathrm{C} / \mathrm{H}$ Mass Ration & Calc. & TBR & & 6.47 \\
\hline Carbon Content, \%m/m & D5291 & TBR & & 86.62 \\
\hline Hydrogen Content, \%m/m & D5291 & TBR & & 13.38 \\
\hline Oxygen Content, \%m/m & $\begin{array}{l}\text { Elem } \\
\text { Anal }\end{array}$ & TBR & & $<0.04$ \\
\hline Carbon Weight Fraction & Calc. & TBR & & 0.8662 \\
\hline Net Calorific Value, BTU & Calc. & TBR & & 18485 \\
\hline Net Calorific Value, MJ/Kg & IP12 & TBR & & 43 \\
\hline $\begin{array}{l}\text { Gross Calorific Value, } \\
\mathrm{MJ} / \mathrm{Kg}\end{array}$ & IP12 & TBR & & 45.84 \\
\hline
\end{tabular}

Table A-2 Analysis of Test Fuels, Biodiesel (FAME, B100), EN14214

\begin{tabular}{|c|c|c|c|c|}
\hline Property (Units) & Method & Min & Max & Results \\
\hline Density @ 15 $\mathrm{C}, \mathrm{Kg} / \mathrm{m} 3$ & $\begin{array}{l}\text { EN ISO } \\
12185\end{array}$ & 860 & 900 & 889.1 \\
\hline Viscosity @ 40 $\mathrm{C}, \mathrm{mm} 2 / \mathrm{s}$ & $\begin{array}{l}\text { EN ISO } \\
3104\end{array}$ & 3.5 & 5 & 5.311 \\
\hline Flash Point, oC & $\begin{array}{l}\text { ISO } \\
2719\end{array}$ & 101 & & 38 \\
\hline Sulphur Content, mg/kg & $\begin{array}{l}\text { BS EN } \\
\text { ISO } \\
20846\end{array}$ & & 10 & 2.2 \\
\hline $\begin{array}{l}\text { Micro Carbon Residue on } \\
10 \% \text { bottoms, } \% \mathrm{~m} / \mathrm{m}\end{array}$ & $\begin{array}{l}\text { EN ISO } \\
10370\end{array}$ & & 0.3 & * \\
\hline Cetane Number & $\begin{array}{l}\text { EN ISO } \\
5165\end{array}$ & 51 & & 55.3 \\
\hline $\begin{array}{l}\text { Sulphated Ash Content, } \\
\% \mathrm{~m} / \mathrm{m}\end{array}$ & $\begin{array}{l}\text { EN ISO } \\
3987\end{array}$ & & 0.02 & $<0.01$ \\
\hline Water Content, mg/kg & $\begin{array}{l}\text { EN ISO } \\
12937\end{array}$ & & 500 & 930 \\
\hline Total Contamination, mg/kg & $\begin{array}{l}\text { EN } \\
12662\end{array}$ & & 24 & 8 \\
\hline $\begin{array}{l}\text { Copper Strip Corrosion, } \\
\text { Rating }\end{array}$ & $\begin{array}{l}\text { EN ISO } \\
2160\end{array}$ & Class 1 & & 1 \\
\hline $\begin{array}{l}\text { Oxidation Stability @ } \\
110^{\circ} \mathrm{C}, \text { Hours }\end{array}$ & $\begin{array}{l}\text { EN } \\
14112\end{array}$ & 6 & & 1.8 \\
\hline Acid Value, $\mathrm{mg} \mathrm{KOH} / \mathrm{g}$ & $\begin{array}{l}\text { EN } \\
14104\end{array}$ & & 0.5 & 0.29 \\
\hline lodine Value & $\begin{array}{l}\text { EN } \\
14111\end{array}$ & & 120 & 115 \\
\hline $\begin{array}{l}\text { Linolenic Acid Methyl Ester, } \\
\% \mathrm{~m} / \mathrm{m}\end{array}$ & $\begin{array}{l}\text { EN } \\
14103 \\
\text { Mod }\end{array}$ & & 12 & 5.38 \\
\hline Ester Content, \%m/m & $\begin{array}{l}\text { EN } \\
14103\end{array}$ & TBR & & 80.2 \\
\hline $\begin{array}{l}\text { Ester Content including } \\
\text { C17's, \%m/m }\end{array}$ & $\begin{array}{l}\text { EN } \\
14103 \\
\text { Mod }\end{array}$ & 96.5 & & 80.6 \\
\hline $\begin{array}{l}\text { Polyunsaturated Methyl } \\
\text { Ester, \%m/m }\end{array}$ & $\begin{array}{l}\mathrm{EN} \\
15779\end{array}$ & & 1 & 1.06 \\
\hline Methanol Content, \%m/m & $\begin{array}{l}\text { EN } \\
14110\end{array}$ & & 0.2 & 1.66 \\
\hline $\begin{array}{l}\text { Monoglyceride Content, } \\
\% \mathrm{~m} / \mathrm{m}\end{array}$ & $\begin{array}{l}\text { EN } \\
14105\end{array}$ & & 0.8 & 0.94 \\
\hline Diglyceride Content, \%m/m & $\begin{array}{l}\text { EN } \\
14105\end{array}$ & & 0.2 & 2.29 \\
\hline Triglyceride Content, \%m/m & $\begin{array}{l}\text { EN } \\
14105\end{array}$ & & 0.2 & 10.5 \\
\hline Free Glycerol, \%m/m & $\begin{array}{l}\text { EN } \\
14106\end{array}$ & & 0.02 & $<0.01$ \\
\hline Total Glycerol, \%m/m & $\begin{array}{l}\text { EN } \\
14105\end{array}$ & & 0.25 & 1.66 \\
\hline $\begin{array}{l}\text { Sodium \& Potassium } \\
\text { Content, mg/Kg }\end{array}$ & $\begin{array}{l}\text { EN } \\
14108 \\
\& \\
14109\end{array}$ & & 5 & 56 \\
\hline $\begin{array}{l}\text { Calcium \& Magnesium } \\
\text { Content, mg/Kg }\end{array}$ & $\begin{array}{l}\text { EN } \\
14538\end{array}$ & & 5 & 53 \\
\hline Phosphorus Content, mg/kg & $\begin{array}{l}\text { EN } \\
14107\end{array}$ & & 4 & 5.8 \\
\hline CFPP, ${ }^{\circ} \mathrm{C}$ & $\begin{array}{l}\text { BS EN } \\
116\end{array}$ & TBR & & -7 \\
\hline
\end{tabular}


Table A-3 Elemental Analysis of Test Fuels

\begin{tabular}{|l|l|l|l|l|}
\hline Property & Units & Method & $\begin{array}{l}\text { Ref. } \\
\text { Fuel } \\
\text { (B0; } \\
\text { RF06) }\end{array}$ & $\begin{array}{l}\text { FAME } \\
\text { (B100) }\end{array}$ \\
\hline Carbon & $\mathrm{mass}$ & ASTM D5291 & $86.78 \%$ & $77.39 \%$ \\
\hline Hydrogen & $\mathrm{mass}$ & ASTM D5291 & $13.55 \%$ & $12.15 \%$ \\
\hline Aluminium & $\mathrm{mg} / \mathrm{kg}$ & ICP & 1.7 & 4 \\
\hline Barium & $\mathrm{mg} / \mathrm{kg}$ & ICP & 0.3 & 0.9 \\
\hline Boron & $\mathrm{mg} / \mathrm{kg}$ & ICP & 0.1 & 0.1 \\
\hline Cadmium & $\mathrm{mg} / \mathrm{kg}$ & ICP & $<0.1$ & $<0.1$ \\
\hline Calcium & $\mathrm{mg} / \mathrm{kg}$ & ICP & 6.2 & 4.1 \\
\hline Chromium & $\mathrm{mg} / \mathrm{kg}$ & ICP & 0.5 & 0.1 \\
\hline Copper & $\mathrm{mg} / \mathrm{kg}$ & ICP & 0.1 & 0.2 \\
\hline Iron & $\mathrm{mg} / \mathrm{kg}$ & ICP & 2.3 & 1.5 \\
\hline Lead & $\mathrm{mg} / \mathrm{kg}$ & ICP & 0.1 & 0.1 \\
\hline Magnesium & $\mathrm{mg} / \mathrm{kg}$ & ICP & 0.8 & 1.1 \\
\hline Manganese & $\mathrm{mg} / \mathrm{kg}$ & ICP & $<0.1$ & $<0.1$ \\
\hline Molybdenum & $\mathrm{mg} / \mathrm{kg}$ & ICP & $<0.1$ & $<0.1$ \\
\hline Nickel & $\mathrm{mg} / \mathrm{kg}$ & ICP & 0.3 & $<0.1$ \\
\hline Phosphorus & $\mathrm{mg} / \mathrm{kg}$ & ICP & 0.2 & 0.2 \\
\hline Potassium & $\mathrm{mg} / \mathrm{kg}$ & ICP & 0.4 & 2.3 \\
\hline Silicon & $\mathrm{mg} / \mathrm{kg}$ & ICP & 0.3 & 3.8 \\
\hline Silver & $\mathrm{mg} / \mathrm{kg}$ & ICP & 0.1 & 0.1 \\
\hline Sodium & $\mathrm{mg} / \mathrm{kg}$ & ICP & 1.6 & 15.3 \\
\hline Tin & $\mathrm{mg} / \mathrm{kg}$ & $\mathrm{ICP}$ & $<0.1$ & $<0.1$ \\
\hline Titanium & $\mathrm{mg} / \mathrm{kg}$ & ICP & $<0.1$ & $<0.1$ \\
\hline Vanadium & $\mathrm{mg} / \mathrm{kg}$ & ICP & 0.2 & 0.3 \\
\hline Zinc & $\mathrm{mg} / \mathrm{kg}$ & $\mathrm{ICP}$ & & \\
\hline
\end{tabular}

